\title{
3- Uzaktan eğitime yakından bakış: Bir metafor çalışması
}

Neslihan KARAKUŞ²

\section{Mehmet Önder KARACAOĞLU3}

APA: Karakuş, N.; Karacaoğlu, M. Ö. (2021). Uzaktan eğitime yakından bakış: Bir metafor çalışması. RumeliDE Dil ve Edebiyat Araştırmaları Dergisi, (Ö10), 44-62. DOI: 10.29000/rumelide.1009038.

Öz

Covid-19 salgını ile birlikte eğitim-öğretim faaliyetleri büyük bir değişime uğramış, zorunlu olarak geçilen uzaktan eğitim ile yeni bir süreçle karşı karşıya kalınmıştır. Tüm dünyayı etkisi altına alan salgın süreciyle birlikte Türkiye'de eğitimin tüm kademelerinde uzaktan eğitime geçilmiştir. Eğitimöğretim faaliyetleri bilgisayar, tablet, cep telefonu, televizyon gibi iletişim araçları vasıtasıyla, uzaktan eğitim ile sürdürülmüştür. Bu bağlamda gerçekleştirilen eğitim-öğretimin geleneksel eğitime kıyasla sahip olduğu avantajlar ve dezavantajlar bilim insanlarınca incelenmeye başlanmıştır. Bu çalışmada eğitimin paydaşlarının sürece dair görüşlerinin metaforlar aracılığıyla incelenmesi amaçlanmıştır. Covid-19 salgınının etkisiyle, hızlı geçiş ve değişimlerle birlikte yapılandırılan uzaktan eğitimin uygulama aşamalarında karşılaşılan durumların ortaya konulması, eğitim paydaşlarının algıları çerçevesinde incelenmesi büyük önem taşımaktadır. $\mathrm{Bu}$ çalışmanın amacı, eğitimin tüm paydaşlarının (öğrenci, öğretmen ve veli) uzaktan eğitime bakışlarını metaforlar aracılı̆̆ıyla değerlendirmektir. Bu bağlamda araştırmanın üç çalışma grubu bulunmaktadır. Öğrenci, öğretmen ve veli çalışma gruplarına yönelik ayrı ayrı hazırlanan görüşme formları Google Forms üzerinden dijital içeriğe dönüştürülmüş ve paydaşlara uygulanmıştır. Olgu bilim araştırması olarak yürütülen çalışmada elde edilen metaforik veriler, içerik analiziyle çözümlenmiştir. Metaforların tasnifiyle birlikte algıların yoğunlaştığı temalar belirlenmiştir. Araştırmanın sonuçlarına göre uzaktan eğitimin metaforik algısında geçici ve verimden uzak olması, yüz yüze eğitimin yerine ikame edilmesi ve ruhsuz, duygusuz, sosyalleşmeden uzak bir süreç olarak ifade edilmesi ortaya konulmuştur. Araştırmaya katılan eğitim paydaşları görüşleri bağlamında sürecin daha verimli kılınabilmesi adına birtakım öneriler getirilmiştir.

Anahtar kelimeler: Uzaktan eğitim, eğitim paydaşları, metafor, Covid-19

\section{A close look at distance education: A metaphor study}

\author{
Abstract \\ With the Covid-19 epidemic, education and training activities have undergone a great change, and a \\ new process has been encountered with the compulsory distance education. With the epidemic \\ process that affected the whole world, distance education has been started at all levels of education \\ in Turkey. Education-teaching activities were carried out by means of communication tools such as \\ computers, tablets, mobile phones and televisions, with distance education. In this context, the \\ Yıldız Teknik Üniversitesi, Sosyal Bilimler Enstitüsü Yayın Etiği Kurulunun 17365429 sayılı yazısı ile araştırma için gerekli \\ olan etik kurul iszni alınmıștır. \\ Doç. Dr., Ylldız Teknik Üniversitesi, Eğitim Fakültesi, Türkçe ve Sosyal Bilgiler Eğitimi ABD (İstanbul, Türkiye), \\ neslihankarakush@gmail.com, ORCID ID: 00oo-0001-7808-1099 [Araştırma makalesi, Makale kayıt tarihi: 25.09.2021- \\ kabul tarihi: 20.10.2021; DOI: 10.29000/rumelide.1009038] \\ MEB, Türkçe Öğretmeni, Doktora Öğrencisi, Ylldız Teknik Üniversitesi, Sosyal Bilimler Enstitüsü, Türkçe ve Sosyal \\ Bilimler Eğitimi Doktora Programı (İstanbul, Türkiye), mehmetonder25@gmail.com, ORCID ID: 0000-0002-4461-6021 \\ Adres | Address \\ RumeliDE Dil ve Edebiyat Araşturmalar Dergisi $\quad$ RumeliDE Journal of Language and Literature Studies \\ Osmanağa Mahallesi, Mürver Çiçeği Sokak, No:14/8 Osmanağa Mahallesi, Mürver Çiçeği Sokak, No:14/8 \\ Kadıköy - ISTANBUL / TÜRKIYE 34714 Kadıköy - ISTANBUL / TURKEY 34714 \\ e-posta: editor@rumelide.com e-mail: editor@rumelide.com, \\ tel: +90 505 7958124, +90 216773 o 616 phone: +90 505 7958124, +90 2167730616
}


advantages and disadvantages of education and training compared to traditional education have been started to be examined by scientists. In this study, it is aimed to examine the views of the education stakeholders about the process through metaphors. It is of great importance to reveal the situations encountered in the implementation stages of distance education, which is structured with the effect of the Covid-19 epidemic, along with rapid transitions and changes, and to examine it within the framework of the perceptions of education stakeholders. The purpose of this study is to evaluate the perspectives of all stakeholders (students, teachers and parents) on distance education through metaphors. In this context, the study has three study groups. Interview forms prepared separately for student, teacher and parent study groups were converted into digital content via Google Forms and applied to stakeholders. The metaphorical data obtained in the study conducted as a phenomenological research were analyzed by content analysis. With the classification of the metaphors, the themes in which the perceptions intensified were determined. According to the results of the research, it has been revealed that distance education is temporary and far from efficiency in the metaphorical perception, it is substituted for face-to-face education and it is expressed as a soulless, emotionless and socialization process. In the context of the opinions of the education stakeholders participating in the research, some suggestions were made in order to make the process more efficient.

Keywords: Distance education, education stakeholders, metaphor, Covid-19

\section{Giriş}

2019 ylının sonlarında Çin'in Wuhan kentinde ortaya çıan ve 2020 itibarıyla ülkemizin de içinde bulunduğu birçok ülkeyi etkisi altına alan Covid-19 adlı Koronavirüs salgını dünya genelinde çok büyük etkiler yaratmıştır. Dünya Sağlık Örgütü tarafindan küresel salgın (pandemi) olarak kabul edilen Covid19'un etkileri tüm dünyada olağan yaşamı çok farklı bir boyuta taşımıştır. Dünyada bugüne değin karşılaşlan en büyük küresel salgınlardan biri olan Covid-19 insanların eğitimden alışverişe, sosyal hayattan eğlenceye, tatilden sağlı̆̆a, hukuktan siyasete kadar her anını etki ve sonuçlarıyla farklı bir mecraya taşımıştır. Tedbirler alınmış, kısıtlamalar ilan edilmiş, ülkeler arası seyahatlerden şehirler arası ulaşıma kadar birçok farklı uygulama hayatın rutin akışını değiştirmiştir.

İnsanoğlu hayatını sürdürme sürecinde birçok farklı olumsuz durumla karşılaşabilmektedir. Savaşlar, afetler, göçler, depremler yaşamın rutin seyrinde değişikliklere yol açabilmekte; ülkeler büyük çaplı etkileri olan bu durumlara karşı kendi refleksleri çerçevesinde tedbirler alabilmektedir. Hükümetler eğitim-öğretim sürecinin aksamadan ve sağlıklı bir şekilde yürümesi için gereken tüm tedbirleri almakta, eğitimden sorumlu bakanlıklar diğer bakanlıklarla eşgüdümlü şekilde koordinasyonu sağlamaktadır. Okullarda 26/7/2014 tarih ve 29072 sayılı Resmî Gazete'de yayımlanan Millî Eğitim Bakanlığı Okul Öncesi Ĕgitim ve İlköğretim Kurumları Yönetmeliğinin 7’nci maddesi ile Bakanlıkça veya mülki idare amirliklerince eğitim-öğretime ara verilmesine dair kararlar alınabilmektedir. Ancak bu durum genelde elverişsiz hava koşulları, doğal afetler gibi nedenlerle birkaç günlük ara verilmesi şeklinde olmaktadır. Ülkemizde 11 Mart 2020 tarihinde ilk vaka olarak kayıtlara geçen virüs taşıyan kişinin tespitinin ardından Millî Eğitim Bakanlığı (MEB), Covid-19 salgınına karşı alınan tedbirlere ilişkin açıklama yapmıştır (MEB, 2020). Bu karar ile birlikte birçok ülke ile beraber Türkiye, yüz yüze eğitim öğretim uygulamalarına ara vermek zorunda kalmıştır. Küresel düzeyde örgün eğitim uygulamalarının yürütülememesi büyük bir problem olarak görülmüş, bu problemin çözümünde açı ve uzaktan eğitim uygulamaları temel bir öğrenme kaynağı olarak gündeme gelmiştir (Can, 2020). Millî Eğitim Bakanlığı tüm kademelerde uzaktan eğitime geçişle ilgili kararının ardından bu süreçleri EBA,

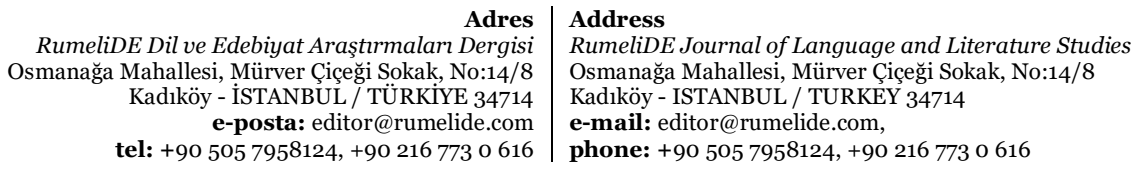


EBA TV aracllığıyla yürüteceğini kamuoyuna duyurmuştur. Resmî/özel tüm kademedeki eğitim kurumlarını kapsayan bu kararla birlikte uzaktan eğitime geçişe yönelik işlemler başlatılmıştır. İlk başta kısa bir süre olarak düşünülen bu uygulama, hastalığın küresel bir salgına dönüşmesi ve hızlı yayılımıyla birlikte birkaç kez uzatılmıştır. Yüksek Öğretim Kurulu (YÖK) da 13 Mart 2020 tarihinde yayınladığı bilgi notuyla uzaktan eğitime ilişkin kararları açıklamıştır. Bu kararlara istinaden "7. Uzaktan öğretimle ilgili usul ve esaslara göre açllmış, hâlihazırda uzaktan eğitimle yürütülmekte olan programların, uygulamah ve yüz yüze eğitimleri hariç olmak üzere, eğitimlerine devam etmesine" karar verilmiştir (YÖK, 2020). Salgınla birlikte eğitim-öğretim süreçleri ve ölçme-değerlendirme uygulamaları sekteye uğramış, yeni tedbirler alınmasını beraberinde getirmiştir. 08 Mayıs 2020 tarih 31121 sayılı Millı̂ Eğitim Bakanlığı Okul Öncesi Eğitim ve İlköğretim Kurumları Yönetmelik değiş̧ikliği ile "Bu Yönetmeliğin 7 nci maddesine göre eğitim ve öğretim faaliyetlerine ara verilmesi durumunda uzaktan eğitim yapılabilir. Ancak uzaktan eğitimde puanla değerlendirme yapılmaz" fikrası eklenmiş ve uzaktan eğitim resmî olarak da hayatımıza girmiştir. 2019-2020 eğitim-öğretim yılının uzaktan eğitimle bu şekilde sürdürülmesi ve birinci dönemde verilen notların eğitim-öğretim yılının tamamını kapsayacak şekilde kullanılmasının ardından 2020-2021 eğitim öğretim yılı itibarıyla salgının seyrindeki azalma ve öğrencilerin okul ortamından uzak bulunuşunun oluşturacağı tahribat değerlendirilmiş, kademeli ve seyreltilmiş bir şekilde hibrit bir eğitim-öğretim modeli planlanmıştır. Millı̂ Eğitim Bakanlı̆̆ı, Covid-19 Koronavirüsle Mücadele Bilim Kurulu kararlarına istinaden 1, 8 ve 12. sınıflarda haftanın bazı günleri ve seyreltilmiş sınıflarda eğitim-öğretim başlatılmasını kararlaştırılmıştır. Kısa bir süre sonra ise 2, 3, 4, 5 ve 9. sinıflarda benzer bir uygulama yürürlüğe konulmuştur. Ancak sonbaharda artan vaka sayıları ile 17 Kasım 2020 tarihinde T. C. Cumhurbaşkanlığı İletişim Başkanlığı tarafindan yapılan açıklama ile tekrar uzaktan eğitime geçilmiş ve 4 Ocak 2021'e kadar resmî/özel her türdeki eğitim kurumundaki yüz yüze eğitim faaliyetleri sonlandırılmıştır. Salgının seyrindeki olumsuz gelişmeler, artan vefatlar ve vaka sayıları bilim kurulu tarafından masaya yatırılmış ve yeni tedbirlerin alınması gerekliliğiyle karşı karşıya kalınmıştır. $\mathrm{Bu}$ tedbirler kapsamında ise her türdeki eğitim kurumunda yüz yüze eğitimin başlamayacağı, ilk, orta ve lise dengi tüm eğitim kurumlarında 22 Ocak 2021 tarihinde başlayacak olan yarı yıl tatiline kadar uzaktan eğitime devam edileceği ifade edilmiştir. 22 Ocak - o7 Şubat aralığını kapsayan tatile 12-16 Nisan tarihlerinde yapılması gereken ara tatilde eklenerek eğitim öğretimin 15 Şubat 2021'de başlaması öngörülmüş̧ür. Millî Eğitim Bakanlığı merkezî sinavları dikkate alarak resmî/özel eğitim kurumlarında 8 ve 12. sınıflara yönelik Destekleme ve Yetiştirme Kurslarına (DYK) yüz yüze eğitim izni vermiştir. Bunlar dışındaki tüm süreçlerin bilim kurulunun alacağı kararlara göre şekillendirileceği ve uzaktan eğitimin devam edeceği duyurulmuştur. Hızla değişen bu süreç öğrencilerin salgından uzak tutulması mantığıyla oluşturulurken öğrencilerin okuldan uzak kalmasının, ekrandan eğitim-öğretim yapılmasının, hareketsiz kalmanın, evlere kapanmanın oluşturacağı tahribat psikolojik ve fizyolojik açıdan değerlendirilmeye başlanmıştır. Bu tartışmaların gölgesinde başlayan eğitim-öğretim yllı ikinci döneminde 15 Şubat Pazartesi günü köy okullarında tüm kademelerde eğitimöğretim başlamış; 1 Mart Pazartesi günü itibarıyla il ve ilçe merkezlerinde de ortaokul 8. sınıflarda, lise 12. sinıflarda, okul öncesi ve ilkokullarda ise tüm düzeylerde eğitim öğretime başlanacağı; bu durumun bilim kurulu kararları doğrultusunda güncellenebileceği duyurulmuştur. Nitekim bilim kurulunun tavsiyeleri doğrultusunda bu durum illerdeki risk durumlarına göre güncellenmiş ve "yerinden karar" kavramıla birlikte illerin risk durumlarına göre karar alınması uygulamasına geçilmiştir.

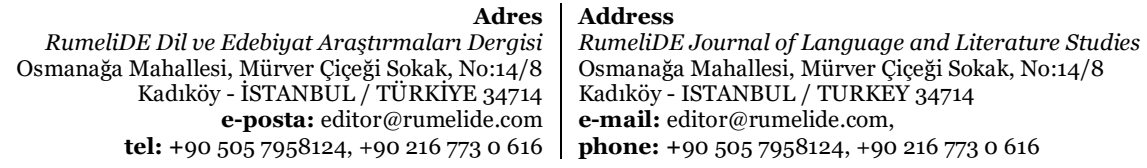

Adres
RumeliDE Dil ve Edebiyat Araştırmaları Dergisi tel: +90 505 7958124, +90 2167730616 


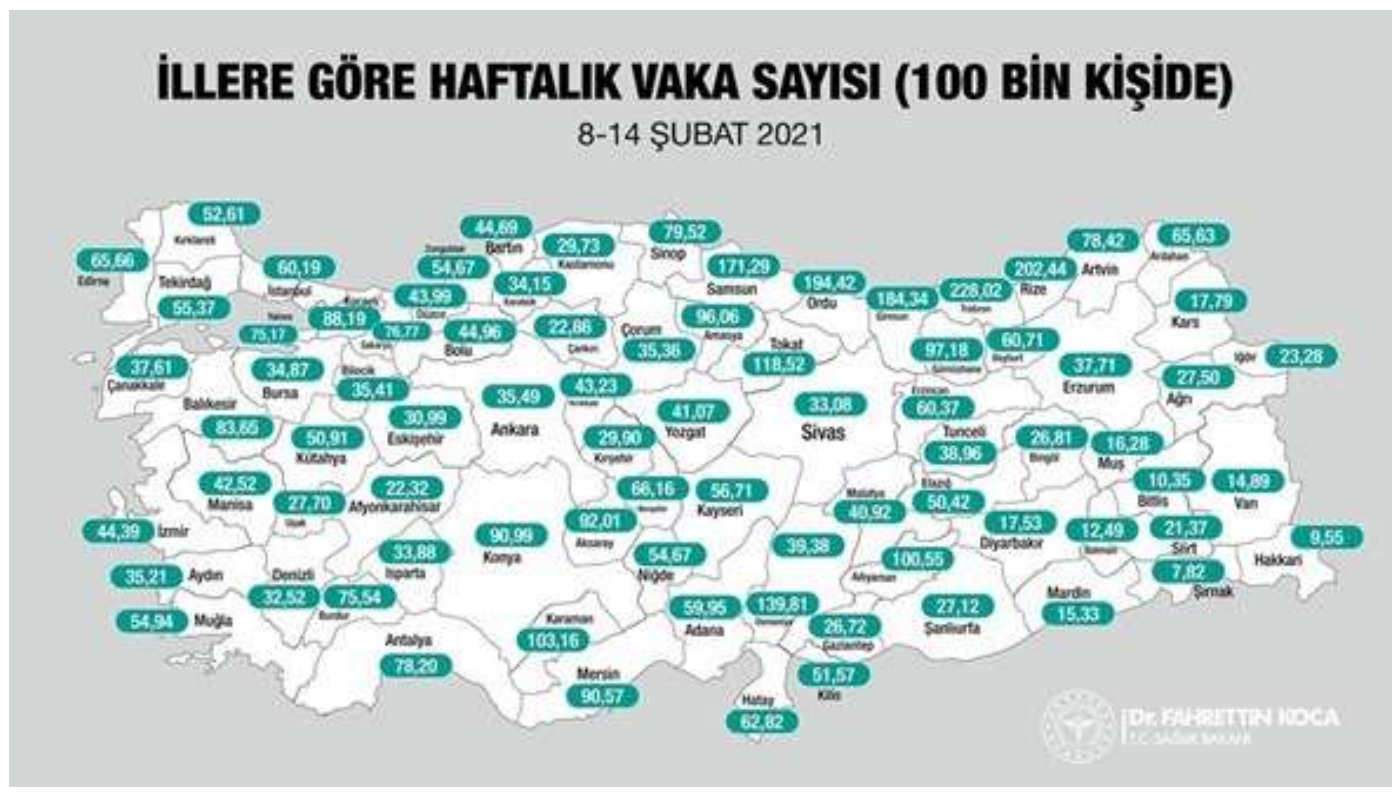

Görsel 1. Sağhlk Bakanlı̆̆ tarafindan sunulan 8-14 Şubat 2021 haftası illere göre vaka sayıları

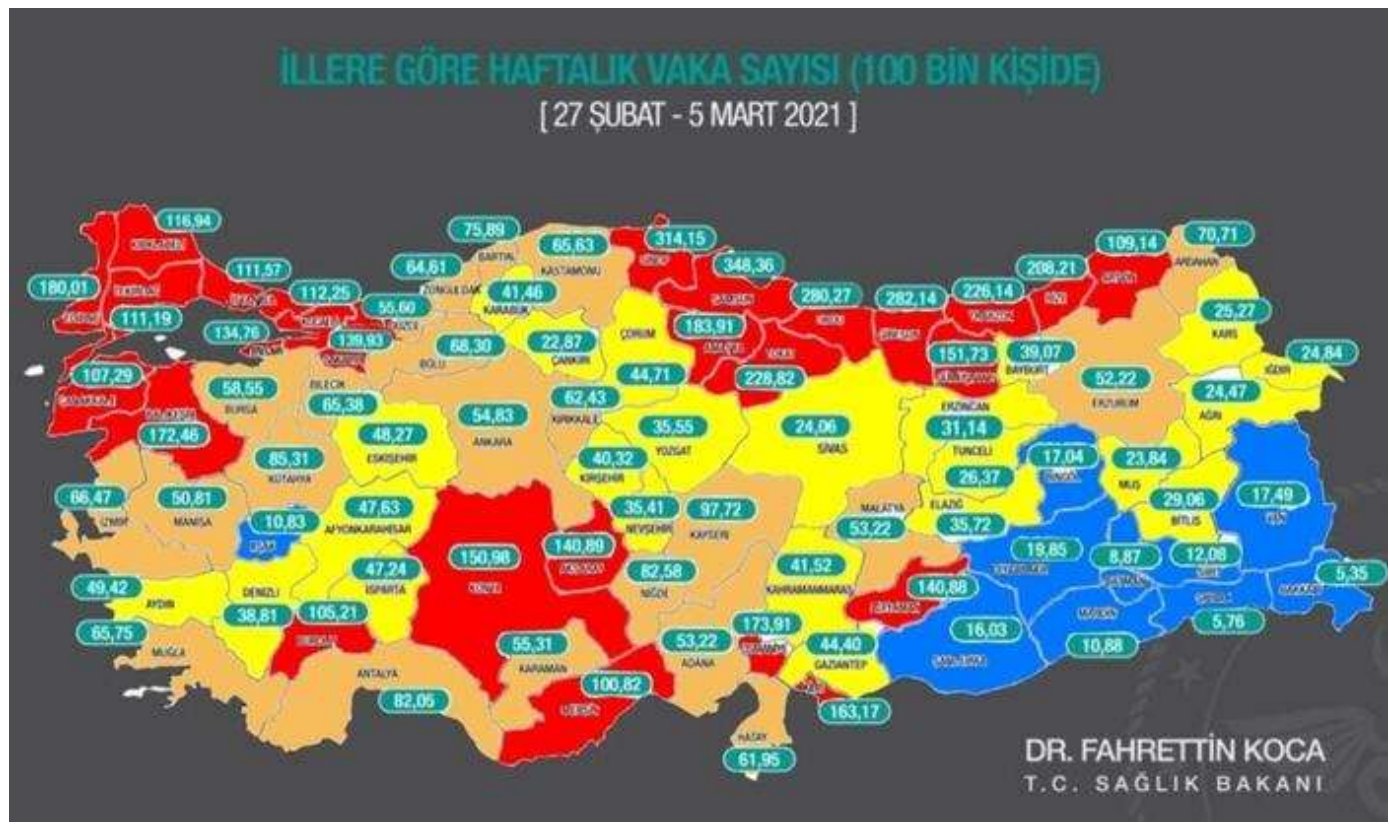

Görsel 2. Sağhk Bakanhğının renk kategorili 27 Şubat - 5 Mart 2021 haftası vaka sayısı haritası (Kırmızı renk, çok yüksek riskli; turuncu, yüksek riskli; sarı, orta riskli; mavi, düşük riskli illeri göstermektedir.)

RumeliDE Dil ve Edebiyat Araştırmaları Dergisi Osmanağa Mahallesi, Mürver Çiçeği Sokak, No:14/8 Kadıköy - ISTANBUL / TÜRKIYE 34714 e-posta: editor@rumelide.com tel: +90 505 7958124, +90 2167730616
Address

RumeliDE Journal of Language and Literature Studies Osmanağa Mahallesi, Mürver Çiçeği Sokak, No:14/8

Kadıköy - ISTANBUL / TURKEY 34714

e-mail: editor@rumelide.com

phone: +90 505 7958124, +90 2167730616 


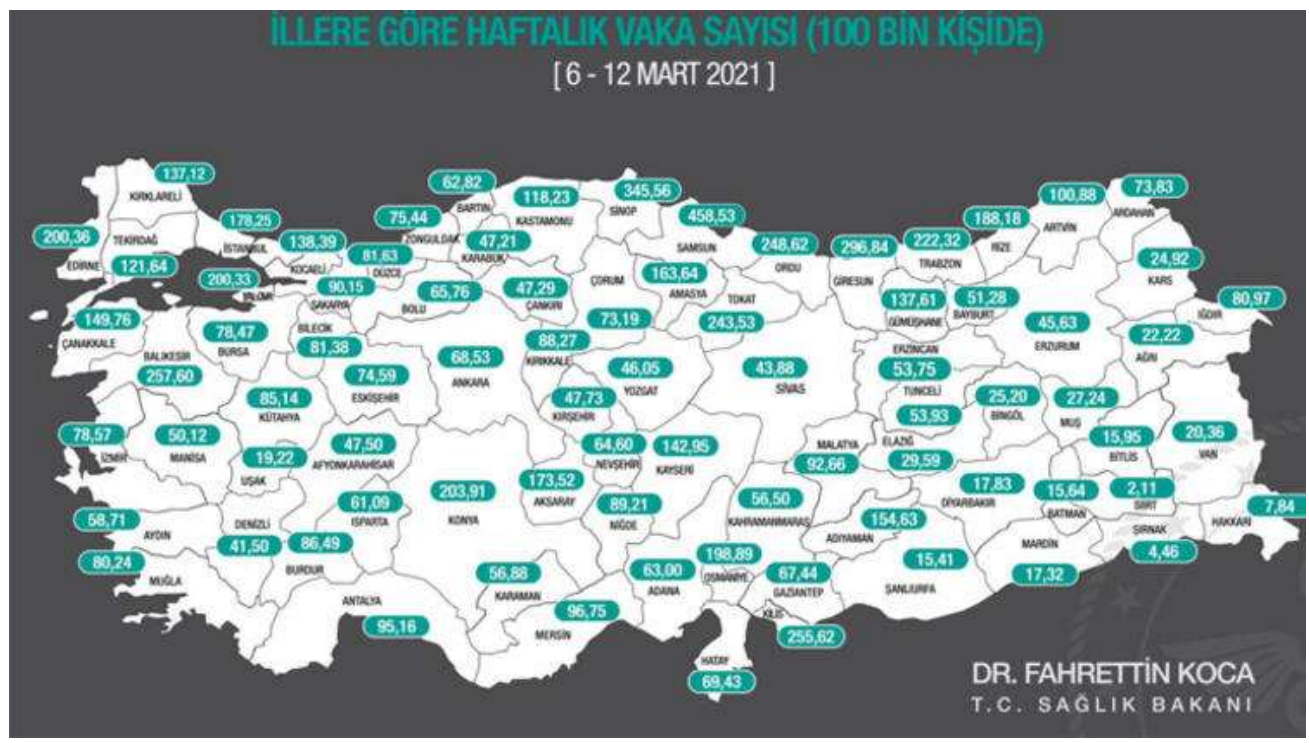

Görsel 3. Eğitim-öğretime uzaktan eğitimle devam edilme kararı alındiğı süreçte iller bazmda vaka sayıları

Türkiye Cumhuriyeti Sağlık Bakanlığı tarafından yayınlanan risk haritalarına göre İllerin risk durumu, renklere göre sınıflandırılmıştır. Buna göre; mavi gruptaki renkler düşük riskli, sarı gruptaki şehirler orta riskli, turuncu gruptaki renkler yüksek riskli ve kırmızı gruptaki iller çok yüksek riskli renk kodu ile kodlanmıştır. Bu kodlara göre tedbirlerin devamı ve "yerinden karar" süreci öngörülmüştür. Mart ayı itibarıyla düşük ve orta riskli illerde eğitim-öğretim tüm kademelerde seyreltilmiş olarak sürdürülmektedir. Vakaların çok düşük olduğu illerde tam zamanlı eğitim-öğretim yapılması mülki idare amirliklerine bırakılmıştır. Yüksek ve çok yüksek riskli olarak kodlanan il ve ilçelerde ise anaokulu, ilkokul 1. sınıf, ortaokul 8. sınıf ve lise 12. sınıflarda eğitim-öğretimin seyreltilmiş olarak yüz yüze sürdürülmesi kararlaştırılmıştır. Millı̂ Eğitim Bakanlığı 2020-2021 eğitim-öğretim ylı ikinci döneminde sınavların yapılacağını, yüz yüze ve uzaktan eğitimin birlikte sürdürülmesinden hareketle sinavlarda tüm süreçlerden sorumlu olunacağını ilan etmiştir. Yani uzaktan eğitim bu noktada da etkinliğini sürdürecek ve belki de bundan sonraki tüm eğitim-öğretim süreçlerinde var olmaya devam edecektir.

Covid-19 sürecinden bağımsız şekilde düşünülerek uzaktan eğitimin ülkemizdeki gelişimine bakıldığında Anadolu Üniversitesi, Atatürk Üniversitesi, Sakarya Üniversitesi, İstanbul Üniversitesi, Marmara Üniversitesi, Kocaeli Üniversitesi, İnönü Üniversitesi, Hoca Ahmet Yesevî Uluslararası TürkKazak Üniversitesi gibi birçok üniversitede uzaktan eğitim programlarının bulunduğu ve uzaktan eğitimle sürdürülen önlisans, lisans, lisansüstü programlarının olduğu bilinmektedir. Ayrıca üniversiteler bünyesinde faaliyet gösteren ve sertifikalı eğitimler düzenleyen merkezlerin de uzaktan eğitim altyapısı ile hizmet verdiği görülmektedir. Millî Eğitim Bakanlı̆̆ı ise okullarda teknolojinin daha etkin ve verimli kullanılması amacıyla başlattığı Fatih Projesi ile Eğitim Bilişim Ağı'nın (EBA) interaktif bir portal olması yönünde çalışmalar yürütmektedir. Okullara etkileşimli tahtaların montajı ve öğrencilere tablet bilgisayarların dağıtımı gibi çalışmalarla eğitimde dijital uygulamaların alt yapısını oluşturulmuştur (Bayburtlu, 2020). Ayrıca Millı̂ Eğitim Bakanlığı son yıllarda düzenlediği Eğitimde Teknoloji Zirvesi (ETZ) adlı çalışmalarla saha uygulamalarını akademik bir boyuta taşımayı amaçlamaktadır. Tüm bu gelişmelere rağmen Covid-19 ile birlikte olağandışı bir gelişim gösteren uzaktan eğitim süreci farklı sorunları beraberinde getirmiştir. Bu sebeplere bağlı olarak daha önce benzeri yaşanmamış bu sürece dair paydaşların görüşlerinin ortaya çıkarılması, bu hâliyle ilk kez

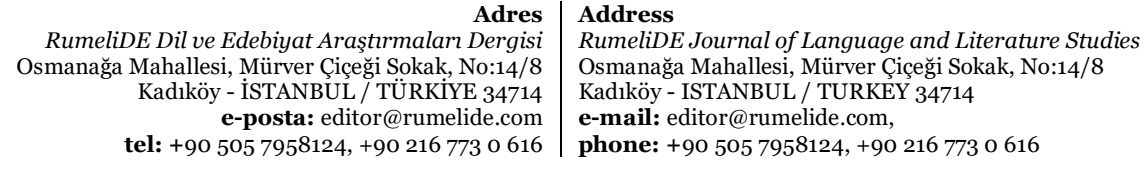


deneyimlenen sürecin olumlu ve olumsuz yanlarının belirlenmesi bilim insanlarının bu konularda çalışma yapmasını da gerekli kılmıştır.

Uzaktan eğitime geçişle birlikte bu süreç araştırmacıların yeni araştırmalarla irdelediği ve değerlendirmelerde bulunduğu bir alan olmuştur. Paydaşların görüşleri, gözlemleri birçok çalışmada ele alınmış benzer ve farklı çalışmalarla sürecin gözler önüne serilmesi amaçlanmıştır.

Yapılan güncel çalışmalar incelendiğinde uzaktan eğitimin etkililiği (Başaran vd., 2020), lisans düzeyinde öğrenim gören öğrencilerinin görüşleri (Karadağ ve Yücel, 2020; Genç ve Gümrükçüoğlu, 2020; Buluk ve Eşitti, 2020; Kürtüncü ve Aylin, 2020; Karakuş vd. 2020), paydaş görüşleri (Özdoğan ve Berkant, 2020), veli görüşleri (Karakuş vd., 2021; Arslan vd., 2021, Akgül ve Oran, 2020), Türkçe dersleri bağlamında ele alan görüşler (Bayburtlu, 2020; Karacaoğlu vd., 2021), öğretmen görüşleri (Balaman ve Hanbay Tiryaki, 2021; Karacaoğlu vd., 2021; Sönmez vd., 2020), Covid19 ile ortaya çlkan eğitim süreci (Kırmızıgül, 2020), uzaktan eğitim uygulamaları ve pedogojik yansımaları (Ertuğ, 2020), sürece ilişkin değerlendirmeler ve yeni normalde eğitim (Bozkurt, 2020), öğretim elemanlarının görüşleri (Şeren vd., 2020) gibi birçok çalışma yapılmıştır. Ayrıca metafor çalışmaları ile de uzaktan eğitimle ilgili tespitler yapılmıştır. Bunlar incelendiğinde ise öğrenci ve öğretmen metaforları (Çokyaman ve Menderes, 2020), öğretmen metaforları (Korkmaz, 2021; Cantürk ve Cantürk, 2021, Kuzu vd., 2020), ortaokul öğrencilerinin metaforları (Akpolat, 2020; Öztürk ve Koca, 2020) ile üniversite öğrencilerinin metaforları (Demirbilek, 2020) çeşitli çalışmalar kapsamında yapılmıştır. Çalışmamızda hem öğrenci hem öğretmen hem de veli metaforları ele alındığından tüm paydaşları ele alan kapsamlı bir çalışma olması yönüyle de eğitim araştırmalarına katkı sağlayacağı değerlendirilmektedir.

Öğretmen, öğrenci, veli gibi paydaşların uzaktan eğitimle yürütülen süreçlere dair görüşlerinin tespit edilmesi, sürecin devamında yapılacak iyileştirmeler açısından önem arz etmektedir. Bu araştırmanın amacı uzaktan eğitimle yürütülen sürece dair öğretmen, öğrenci ve veli metaforlarının incelenerek uzaktan eğitimin, eğitim-öğretim paydaşları tarafindan nasıl algılandığının ortaya konulmasını sağlamaktır. Covid-19 salgınının hayatın olağan akışına olan etkisinin metaforlarla ne şekilde dile getirildiği güncel bir saha araştırması olarak incelenecektir. Araştırmanın alan yazına katkı sunacağı ve bundan sonraki süreçte eğitimin içerisinde yer alacak olan uzaktan eğitimle ilgili altyapı oluşturacağı öngörülmektedir.

\section{Yöntem}

\subsection{Araştırmanın modeli}

$\mathrm{Bu}$ araştırmada nitel araştırma yöntemlerinden olgu bilim çalışması olarak desenlenmiştir. Olgu bilim kapsamında yürütülen çalışmalarda bir olguya yönelik bireysel boyuttaki algıların ya da deneyimlerin bireyler üzerinden incelenmesi amaçlanmaktadır (Creswell, 2007). Olgu bilim içerisinde yer alınan/bulunulan süreçlere dair derinlemesine ve ayrıntılı veri toplamayı esas alan bir araştırma stratejisidir. Olgu bilim araştırmaları belirli bir zaman diliminde ve bağlamda bireylerin süreci ve çevrelerini nasıl deneyimlediklerine dayalı bir araştırma öngörür. Yani olgu bilim araştırmalarında bir süreç içerisindeki bireyin etkileşimleri neticesinde ortaya çıkan olguların neler olduğunu, özelliklerini betimlemeyi ve buna bağlı olarak anlamlandırma ve yorumlamayı amaçlar (Bloor ve Wood, 2006; Çilesiz, 2011; Willig, 2008). Bu çalışmada da uzaktan eğitim süreci içerisinde yer alan öğrenci, öğretmen ve velilerin bu duruma dair metaforik algılarını derinlemesine incelemek amaçlı olarak olgu bilim deseni

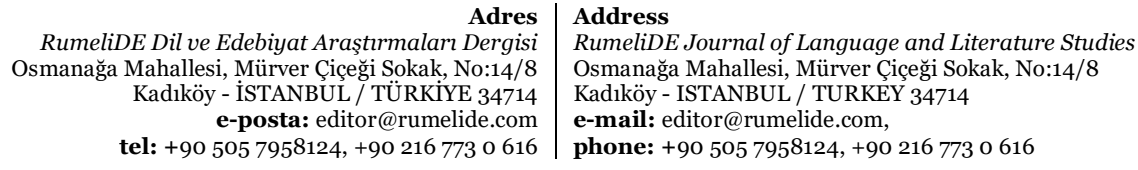


kullanılmıştır. Çalışmada mecazlar yolu ile veri toplama yönteminde karşımıza çıkan metaforlar kullanılmıştır. Mecazlar yoluyla veri toplama yöntemleri arasında yer alan metaforların güçlü bir nitel veri toplama aracı olduğu ve aynı zamanda metaforlar üzerinden farklı alanlardaki en karmaşı düşünce, anlam ve açıllamaların ilişkilendirilebileceği ileri sürülmüştür.

\subsection{Araştırmanın çalışma grubu}

Nitel araştırmalarda elde edilen bulgular evrene genellenmez, süreç ana olgunun derinlemesine ve detaylı bir şekilde keşfedilmesini amaçlamaktadır (Creswell, 2017). Bu bağlamda araştırmalarda genelleme yapmak yerine derinlemesine ve özgün, büyük örneklemler yerine daha küçük çalışma gruplarından elde edilen derin ve özellikli veriler öne çıkmaktadır (Baltacı, 2019). Araştırmanın çalışma grubunda yer alacak hedef kitle ve bireyleri belirlerken ana olgu hakkında bilgi edinmek veya onu anlamak için bireylerin ve araştırma mekânlarının belirli bir amaç ekseninde ele alındı̆̆ 2017) amaçlı örnekleme yönteminden faydalanılmıştır.

Araştırmanın çalışma grubunun belirlenmesinde uzaktan eğitim süreci içerisinde yer alan tüm paydaşların yer almasına dikkat edilmiştir. Çalışma öncesinde belli ölçütlerin belirlendiği ve bu ölçütleri karşılayan durumların seçildiği (Patton, 2014) ölçüt örneklem stratejisi kullanılmıştır. Araştırmanın üç çalışma grubu şöyledir:

- Öğrenci Çalışma Grubu

- Öğretmen Çalışma Grubu

- Veli Çalışma Grubu

\begin{tabular}{llll}
\hline Çalışma Grubu & Erkek & Kadın & Toplam \\
Öğrenci & 30 & 62 & 92 \\
Öğretmen & 22 & 18 & 40 \\
Veli & 33 & 69 & 102 \\
\hline Toplam & 85 & 149 & 234 \\
\hline
\end{tabular}

Tablo 2. Çalışma grupları bazında katılımcı sayıları ve cinsiyet dağılımı

\subsection{Veri toplama araçları, verilerin toplanması ve analizi}

Nitel araştırma süreçlerinde Merriam (2018)'a göre ă̆ sayfaları, dosya transfer protokolü yoluyla mevcut raporlar, elektronik yazılar, görsel programlar; kolayca ulaşlabilen elektronik veri kaynağı, veri toplama aracı, belge ve veri olarak kabul edilirler. Araştırmada veri toplama aracı olarak öğrenci, öğretmen ve velilerden veri toplamak amacıyla görüşme formları hazırlanmıştır.

- Öğrenci Görüşme Formu (Öğretmen Adaylarının Uzaktan Eğitime Yönelik Görüşleri)

- Öğretmen Görüşme Formu (Türkçe Öğretmenlerinin Uzaktan Eğitime Yönelik Görüşleri)

- Veli Görüşme Formu (Ortaokul Öğrenci Velilerin Uzaktan Eğitime Yönelik Görüşleri)

Dört farklı alan uzmanının görüşlerine sunulan formlar, uzmanlardan gelen dönütlere göre düzenlenmiştir. Bu düzenlemenin ardından çalışma grubuna dâhil edilmeyen üç öğrenci, üç Türkçe Adres
RumeliDE Dil ve Edebiyat Araşttrmaları Dergisi
Osmanağa Mahallesi, Mürver Çiçeği Sokak, No:14/8
Kadıköy - İSTANBUL / TÜRKIYE 34714
e-posta: editor@rumelide.com
tel: +90 505 7958124, +90 2167730616
Address

RumeliDE Journal of Language and Literature Studies

Osmanağa Mahallesi, Mürver Çiçeği Sokak, No:14/8

Kadıköy - ISTANBUL / TURKEY 34714

e-mail: editor@rumelide.com,

phone: +90 5057958124, +90 2167730616 
öğretmeni ve üç veli ile bir pilot uygulama yapılmış ve forma son şekli verilmiştir. Formlar ile uzaktan eğitim sürecinin diğer detaylarına dair görüşler derlenmiş ve üç farklı çalışma şeklinde yayımlanmıştır. Paydaşların metaforları ise bu çalışmanın ana eksenini teşkil etmektedir. Görüşme formlarında metafor harici sorularla derinlemesine yapılan analizler araştırmanın yayımlanmış diğer çalışmalarında (Karakuş vd., 2020; Karacaoğlu vd., 2021; Karakuş vd., 2021) yer almaktadır.

Eğitim paydaşlarından elde edilen verilerin analiz sürecinde içerik analizinden faydalanılmıştır. Nitel içerik analizinde amaç, büyük miktardaki veriyi, sistematik olarak önemli sonuçlar doğrultusunda organize ederek yoğun ve kısa bir öze dönüştürmek olmalıdır (Erlingsson, Brysiewicz, 2017). Araştırmanın veri toplama aracı, katılımcı öğrenci, öğretmen ve velilerin uzaktan eğitime yönelik metaforik algılarını almak için Google Forms aracılı̆̆ıyla hazırlanan elektronik görüşme formlarıdır. Eğitim paydaşlarıyla uzaktan erişim yoluyla yapılan bu mülakatlar neticesinde elde edilen metaforik veriler analiz edilmiş, temalandırılmış; süreçle ilgili değerlendirmelerde bulunulmuştur.

\subsection{Araşturma ile ilgili izinler}

Araştırmanın etik izni Yıldız Teknik Üniversitesi Araştırma ve Planlama Rektör Yardımcılığının 25.09.2020 tarih ve 2009250012 sayılı etik kurulu kararı ile alınmıştır. Araştırma öğrenci, öğretmen ve velilerle yürütüleceği için Millı̂ Eğitim Bakanlığı AYSE e-sistemi üzerinden araştırma izni başvurusu yapılmıştır. Manisa İl Millî Eğitim Müdürlüğünün 27.11.2020 tarih 17365429 sayılı izni ile araştırmanın uygulanmasına izin verilmiştir.

\section{Bulgular ve yorumlar}

Eğitim paydaşları olan öğrenci, öğretmen ve velilerin metaforik algılarını belirlemek amacıyla görüşme formlarında yer alan metafor cümleleri/önermeleri analiz edilmiştir. Elde edilen metaforik veriler içerik analiziyle incelenmiş, değerlendirilmiş ve paydaşlar bağlamında tasnifleri yapılmıştır.

Veriler incelenirken cümlelerin/önermelerin verilen "Uzaktan eğitim ...... gibidir. Çünkü ......” formatında olmasına veya buna uygun şekilde kurgulanmış olmasına dikkat edilmiştir.

\begin{tabular}{lll}
\hline Çalışma Grubu & Katılımcı Sayısı & Metafor Sayısı \\
Ö̆ğrenci & 92 & 65 \\
Öğretmen & 40 & 31 \\
Veli & 102 & 32 \\
\hline Toplam & 234 & 128 \\
\hline
\end{tabular}

Tablo 3. Çalş̧ma grupları bazında metafor sayıları

Metafor özelliği taşımayan ifadeler analiz dışı bırakılmış, elde edilen 128 metafor hem kendi kategorileri içerisinde hem de genel bağlamda analiz edilmiştir.

\section{1. Öğrenci metaforları}

Uzaktan eğitim sürecinin sahadaki en önemli paydaşlarından biri öğrencilerdir. Anaokulu, ilkokul, ortaokul, lise ve üniversite düzeyinde farklı uygulamalar ile uzaktan eğitime devam edilmiştir. Çalışmamızın öğrenci ayağında bu sürecin içerisinde alıcı/öğrenen rolündeki bireylerin metaforik

\footnotetext{
Adres $\mid$ Address

RumeliDE Dil ve Edebiyat Araşturmalar Dergisi $\quad$ RumeliDE Journal of Language and Literature Studies Osmanağa Mahallesi, Mürver Çiçeği Sokak, No:14/8 Osmanağa Mahallesi, Mürver Çiçeği Sokak, No:14/8 Kadıköy - İSTANBUL / TÜRKIYE 34714 Kadıköy - ISTANBUL / TURKEY 34714 e-posta: editor@rumelide.com e-mail: editor@rumelide.com, tel: +90 505 7958124, +90 2167730616 phone: +90 505 7958124, +90 2167730616
} 
algıları toplanmıştır. Bu metaforlar ile sürecin nasıl yürüdüğü, verimliliği, olumlu ve olumsuz yanları irdelenmeye çalışılmıştır.

Araştırmanın öğrenci çalışma grubunu Yıldız Teknik Üniversitesi Eğitim Fakültesi Türkçe ve Sosyal Bilimler Eğitimi Bölümünde lisans düzeyinde öğrenim gören üniversite öğrencileri oluşturmaktadır. Öğrencilere ilişkin demografik bilgiler ise şu şekildedir:

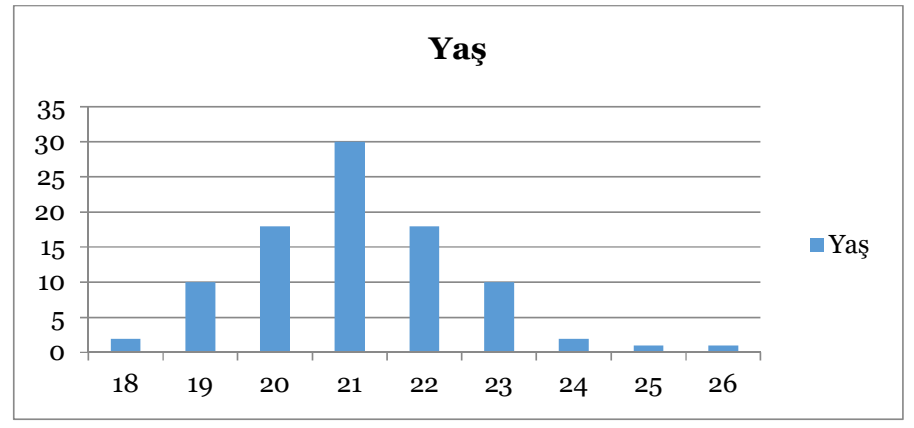

Grafik 1. Öğrencilerin yaş dağılımı grafĭ̆i

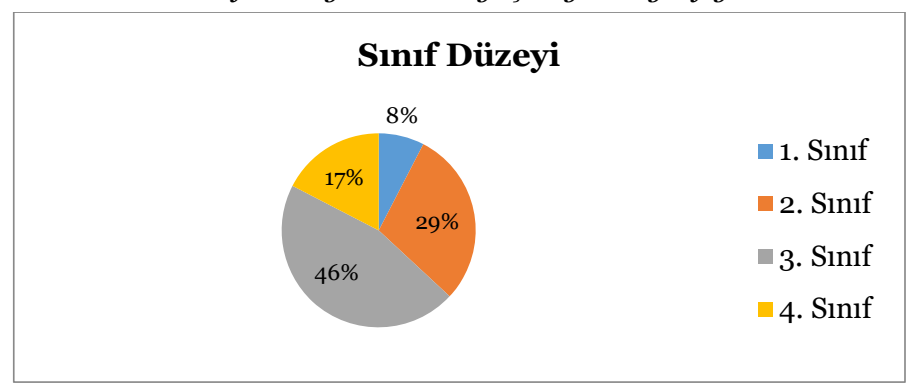

Grafik 2. Öğrencilerin sınıf düzeylerine göre dağılımı

Araştırmanın çalışma grubunu 2019-2020 eğitim-öğretim yılı bahar döneminde Ylldız Teknik Üniversitesi Eğitim Fakültesi Türkçe Eğitimi Ana Bilim dalında lisans düzeyinde 1, 2, 3 ve 4. sinıfta öğrenim görmekte olan 92 Türkçe öğretmeni adayı oluşturmaktadır. Katılımcıların 62'si $(\% 67,4)$ kız, 3o’u $(\% 32,6)$ erkektir. Katılımcıların yaş ve sınıf düzeylerine ilişkin dağılımlar Grafik 1 ve Grafik 2'de verilmiştir.

Metafor çalışmalarında elde edilen metafor cümleleri/önermeleri incelendikten sonra tasnif edilmekte ve temalandırılmaktadır. Öğrenci metaforları ışı̆̆ında yapılan temalandırmada ağırlıklı olarak benzer görüşlerin öne çıktığı dikkat çekmektedir.

\begin{tabular}{ll}
\hline & Geçicilik \\
Temalar & Verimsizlik \\
& Ruhsuzluk \\
& İkame \\
\hline
\end{tabular}

Tablo 4. Öğrenci metaforlarmda temalar

Temalar incelendiğinde öğrenci görüşlerine göre uzaktan eğitimin metaforik algısında geçici olma, verimden uzak olma, yüz yüze eğitimin yerine ikame edilme ve ruhsuz, duygusuz, sosyalleşmeden uzak

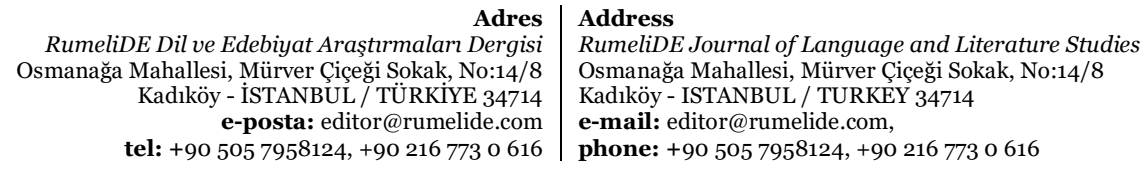


bir süreç olma durumları daha çok ifade edilmiştir. Öğrencilerden elde edilen metaforlardan bazıları şöyledir:

Ö19 : Uzaktan eğitim atıştırmalık gibidir. Çünkü yediğimizde karnımızı doymuş gibi hissetsek de ihtiyacımı olan vitamini, gıdayı almamış oluruz. (Geçicilik)

Ö25 : Uzaktan eğitim altı kopmuş market sepeti gibidir. Sen anladığımı sandıkça sadece ürünlere aşina olursun o bilgiyi tam manasıyla kavrayamazsin. (Verimsizlik)

Ö71 : Uzaktan eğitim jeneratör gibidir. Çünkü yüz yüze eğitimin mümkün olmadığı bir süreçte eğitimin aksamaması için kullanılan bir durumdur. (İkame)

Ö82 : Uzaktan eğitim bilgisayar oyunu gibidir. Çünkü sokak oyunu gibi zevk vermez. (Ruhsuzluk)

Ayrıca öğrenci metaforları incelendiğinde yoğunlaşılan temalar haricinde dikkat çekici bazı metaforlar da yer almaktadır. Bunlardan bazılar şöyledir:

Ö14 : Uzaktan eğitim bir Black Mirror'ın bir bölümü gibidir. Çünkü her şey internete bağh, internet giderse eğitim ve hayat her şey biter gibi. (Şartlara görelik)

Ö33 : Uzaktan eğitim kitap gibidir. Çünkü ne kadar dikkatli okursan o kadar iyi anlarsin. (Faydalılık)

Ö56 : Uzaktan eğitim buz pateni gibidir. Çünkü karşıdan kolay ve zevkli gözükür ancak yapmaya kalkıştığında illa zarar görürsün. (Zorluk)

\section{2. Öğretmen metaforları}

Uzaktan eğitim sürecinin sahadaki en önemli paydaşlarından biri de öğretmenlerdir. Öğretmenler, uzaktan eğitime geçişle birlikte EBA, EBA Destek, EBA Canlı Ders, Zoom, Google Meet, Hangouts, Microsoft Teams, Jitsi Meet, Webex gibi farklı uygulamalar ile uzaktan eğitimi devam ettirmişlerdir. Çalışmamızın öğretmen ayağında bu sürecin içerisinde verici/öğreten rolündeki bireylerin metaforik algıları toplanmıştır. Bu metaforlar ile sürecin nasıl yürüdüğü, verimliliği, olumlu ve olumsuz yanları irdelenmeye çalışılmıştır.

Araştırmanın öğretmen çalışma grubunu Manisa ili Salihli ilçesinde resmî/özel ortaokullar ile imamhatip ortaokullarında görev yapmakta olan Türkçe öğretmenleri oluşturmaktadır. Öğretmenlere ilişkin demografik bilgiler ise şu şekildedir:

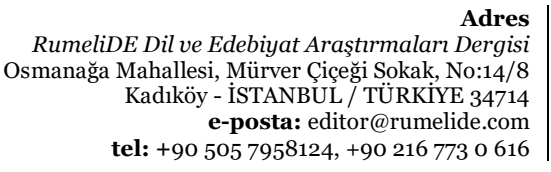

dres

/8

Address

RumeliDE Journal of Language and Literature Studies

Osmanağa Mahallesi, Mürver Çiçeği Sokak, No:14/8

e-mail: editor@rumelide.com,

phone: +90 $5057958124,+902167730616$ 


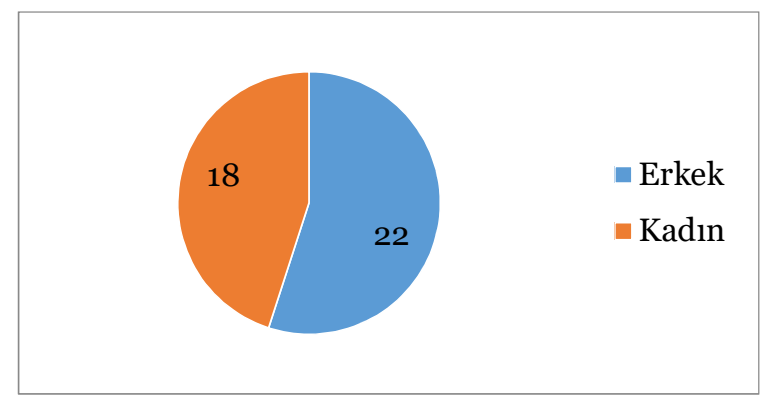

Grafik 3. Öğretmenlerin cinsiyet dağılımı

Araştırmaya gönüllülük esasıyla katılım sağlayan Türkçe öğretmenlerinin 18’i (\%55) kadın, 22’si (\%45) erkektir. Katılımcıların yaşlarına ilişkilerin bilgiler ise Grafik 3’te belirtilmiştir. Yaş dağılımları ise Grafik 4'te yer almaktadır.

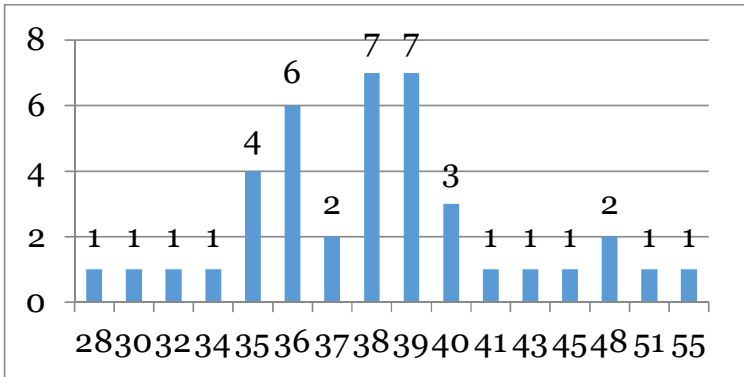

Grafik 4. Öğretmenlerin yaş dağılımı

Grafik 4'e göre öğretmenlerin \%72,5’i 35-41 yaş aralığındaki öğretmenlerdir. Bu yaş grubu teknolojiyi ve buna bağlı olarak da uzaktan eğitimi daha etkin kullanan bireylerden oluşmaktadır. Araştırmaya katılan en genç öğretmen 28 yaşında iken en yaşlı öğretmen ise 55 yaşındadır. Araştırmaya katılan Türkçe öğretmenlerinin eğitim durumlarına ilişkin bilgiler Grafik 5 ve Grafik 6'da belirtilmiştir:

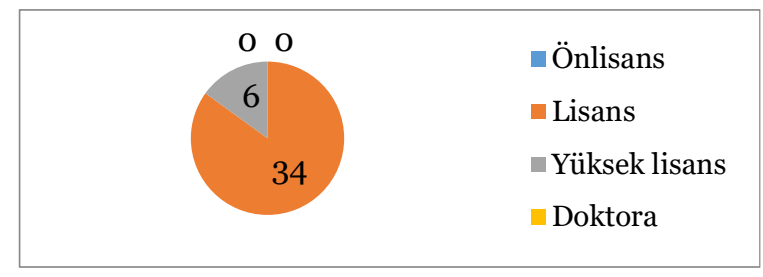

Grafik 5. Öğretmenlerin ĕgitim durumları

RumeliDE Dil ve Edebiyat Araşturmaları Dergisi Osmană̆a Mahallesi, Mürver Çiçeği Sokak, No:14/8 Kadıköy - ISTANBUL / TÜRKIYE 34714 e-posta: editor@rumelide.com tel: +90 $5057958124,+902167730616$
Address

RumeliDE Journal of Language and Literature Studies Osmanağa Mahallesi, Mürver Çiçeği Sokak, No:14/8

Kadıköy - ISTANBUL / TURKEY 34714

e-mail: editor@rumelide.com,

phone: +90 5057958124 , +90 2167730616 


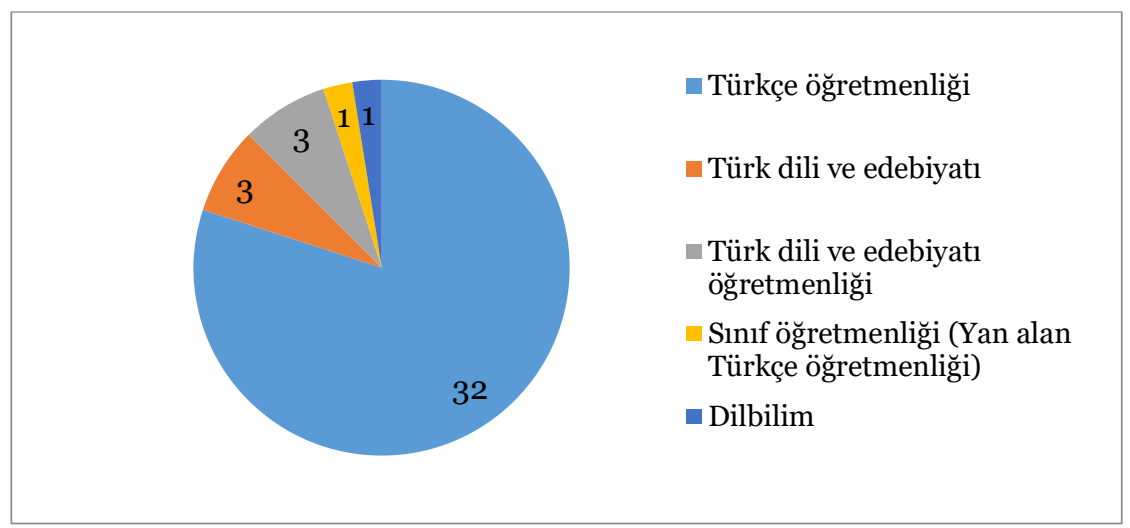

Grafik 6. Öğretmenlerin lisans düzeyinde mezun oldukları bölüm türleri

Grafik 3 ve 4'e göre araştırmanın çalışma grubunda yer alan öğretmenlerin \%85’i (34 öğretmen) lisans, \%15'lik dilimi ise (6 öğretmen) yüksek lisans eğitimine sahiptir. Önlisans ve doktora mezunu öğretmen bulunmamaktadır. Lisans mezunu öğretmenlerin \%80’i (32 öğretmen) Türkçe öğretmenliği mezunudur. Üçer öğretmen Türk dili ve edebiyatı ve Türk dili edebiyatı öğretmenliği mezunu iken bir öğretmen sınıf öğretmenliğinden alan değişikliği ile Türkçe öğretmenliğine geçmiş, bir öğretmen ise dilbilim bölümünden mezun olduğunu ifade etmiştir.

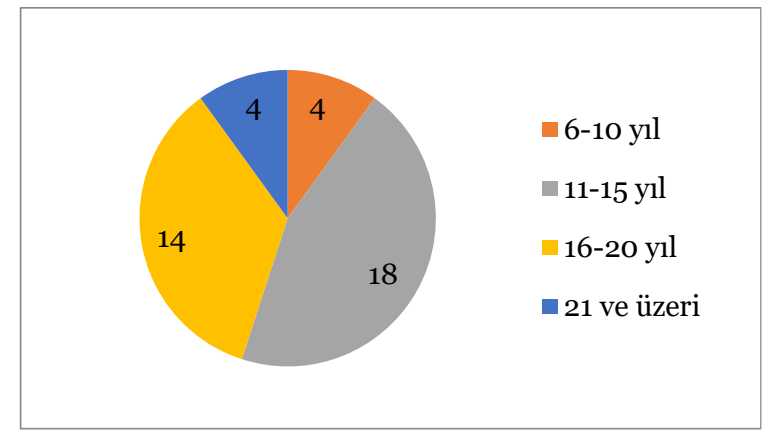

Grafik 7. Öğretmenlerin meslekî kıdemleri

Grafik 5 incelendiğinde çalışma grubunda yer alan öğretmenlerin meslekî kıdemlerine bakıldığında en az kıdeme sahip olanların 6-10 yıl aralığında görev yaptığı görülmektedir. Bu dilimde yer alan öğretmen sayısı 4’tür. Kalan 36 öğretmen ise 11-15 yl (18 katılımcı), 16-20 yll (14 katılımcı) ve 21 ve üzeri (4 katılımcı) meslekî deneyime sahiptir. Bu bilgilerden hareketle çalışma grubunda yer alan öğretmenlerin Türkçe eğitimi konusunda tecrübeli öğretmenler olduğu söylenebilir.

Metafor çalışmalarında elde edilen metafor cümleleri/önermeleri incelendikten sonra tasnif edilmekte ve temalandırılmaktadır. Öğretmen metaforları ışı̆ında yapılan temalandırmada ağırlıklı olarak benzer görüşlerin öne çıktı̆̆ı dikkat çekmektedir.

\begin{tabular}{ll}
\hline & Geçicilik \\
Temalar & Verimsizlik \\
& Ruhsuzluk \\
& İkame \\
\hline
\end{tabular}

Tablo 5. Öğretmen metaforlarında temalar

\begin{tabular}{r|l} 
Adres & Address \\
RumeliDE Dil ve Edebiyat Araştırmaları Dergisi & RumeliDE Journal of Language and Literature Studies \\
Osmanağa Mahallesi, Mürver Çiçeği Sokak, No:14/8 & Osmanağa Mahallesi, Mürver Çiçeği Sokak, No:14/8 \\
Kadıköy - İSTANBUL / TÜRKIYE 34714 & Kadıköy - ISTANBUL / TURKEY 34714 \\
e-posta: editor@rumelide.com & e-mail: editor@rumelide.com, \\
tel: +90 505 7958124, +90 216 773 0616 & phone: +90 505 7958124, +90 2167730616
\end{tabular}


Temalar incelendiğinde öğrenci görüşlerine göre uzaktan eğitimin metaforik algısında geçici olma, verimden uzak olma, yüz yüze eğitimin yerine ikame edilme ve ruhsuz, duygusuz, sosyalleşmeden uzak bir süreç olma durumları daha çok ifade edilmiştir. Türkçe öğretmenlerinden elde edilen metaforlardan bazıları şöyledir:

TÖ3 : Uzaktan eğitim yol yardım gibidir çünkü eğitime geçici bir destektir. Yol yardım seni ve aracın kurtartr ama aracın tamir etmez. (İkame)

TÖ 9: Uzaktan eğitim yalancı emzik gibidir. Çünkü öğrenme gerçek anlamda içselleştirilemiyor. (Ruhsuzluk)

TÖ 26: Uzaktan eğitim rüzgar gibidir çünkü geçicidir. (Geçicilik)

TÖ 31: Uzaktan eğitim kalburla hoşaf taşımak gibidir. Çok çaba harcarsın ama yeterli verimi alamazsm. (Verimsizlik)

Ayrıca öğretmen metaforları incelendiğinde yoğunlaşılan temalar haricinde dikkat çekici bazı metaforlar da yer almaktadır. Bunlardan bazılar şöyledir:

TÖ22 : Uzaktan eğitim bizim kantinin çayı gibi, kantinci nasıl demlerse demlesin kimse beğenmez :) (Görecelik)

TÖ29 :Uzaktan eğitim antibiyotik gibidir. Doğru kullanılırsa çok faydah olur. Yanlış kullanılırsa da faydasından çok zararı olur. (Faydalılık)

TÖ4O : Uzaktan eğitim ananas gibidir. Çünkü herkes yiyemez. (Erişim)

\subsection{Veli metaforları}

Uzaktan eğitim sürecinin sahadaki en önemli paydaşlarından biri de öğrenci velileridir. Veliler normal süreçlerden daha fazla gözlem şansına sahip olmuşlar hatta bir kısmı öğrencilerle birlikte dersleri takip ettiklerini ifade etmişlerdir. Evde devam eden bu süreçte oda sayısı, evin tefrişatı, teknik altyapı, elektronik alet varlığı (bilgisayar, tablet, akıllı telefon gibi), internet aboneliği, internet hızı, bağlantı kalitesi gibi birçok etkenle karşı karşıya kalınmıştır. Çalışmamızın veli ayağında bu sürecin içerisinde gözlemci/sağlayan rolündeki bireylerin metaforik algıları toplanmıştır. Bu metaforlar ile sürecin nasıl gözlemlendiği, verimlilik takibi, olumlu ve olumsuz yanları irdelenmeye çalışılmıştır.

Araştırmanın veli çalışma grubunu Manisa ili Salihli ilçesinde bulunan Millî Egemenlik Ortaokulu öğrenci velileri oluşturmaktadır. Öğrenci velilerine ilişkin demografik bilgiler ise şu şekildedir:

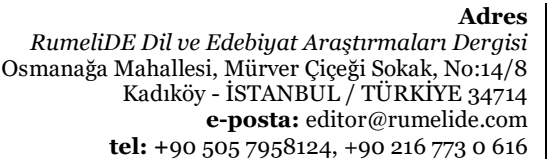

dres 8

Address

RumeliDE Journal of Language and Literature Studies

Osmanağa Mahallesi, Mürver Çiçeği Sokak, No:14/8

Kadıköy - ISTANBUL / TURKEY 34714

-mail: editor@rumelide.com,

phone: +90 5057958124 , +90 2167730616 


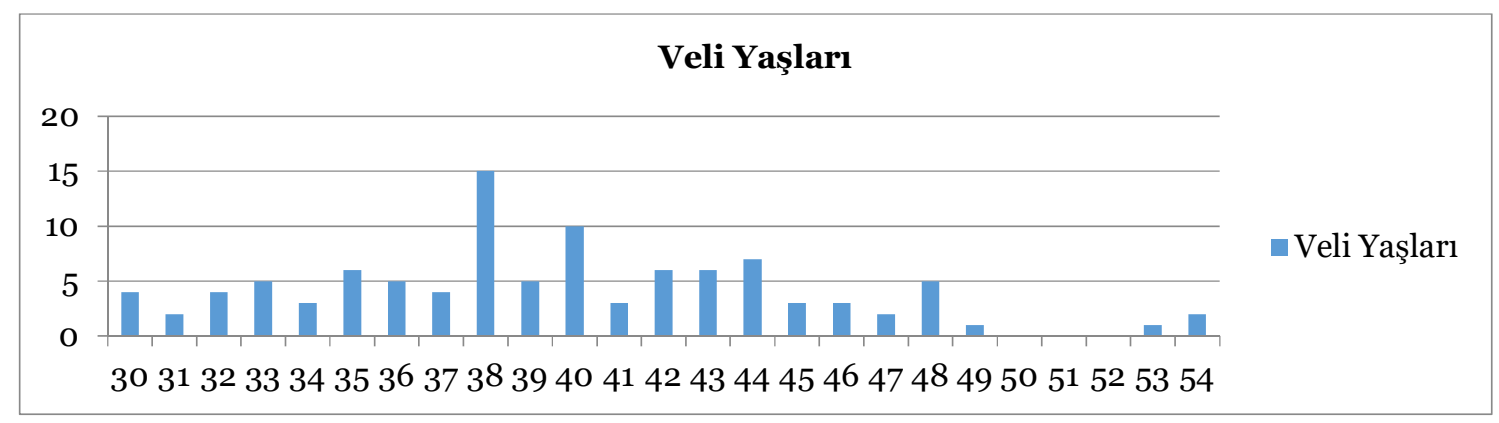

Grafik 8. Öğrenci velilerinin yaş dağılımı

$\mathrm{Bu}$ çalışma grubunun öğrenci velilerinden oluşmasından ötürü katılımcı yaş grubu çeşitlilik göstermektedir. Şekilden hareketle en fazla $(\mathrm{f}=15, \% 14,7)$ tekrar eden değerin 38 olduğu görülmektedir. Ardından (f=10, \%9,8) 40 değeri gelmektedir. Öğrenci velilerinin yaşları, en az 30, en fazla 55 olacak şekilde 30-55 yaş aralığında dağılım göstermektedir.

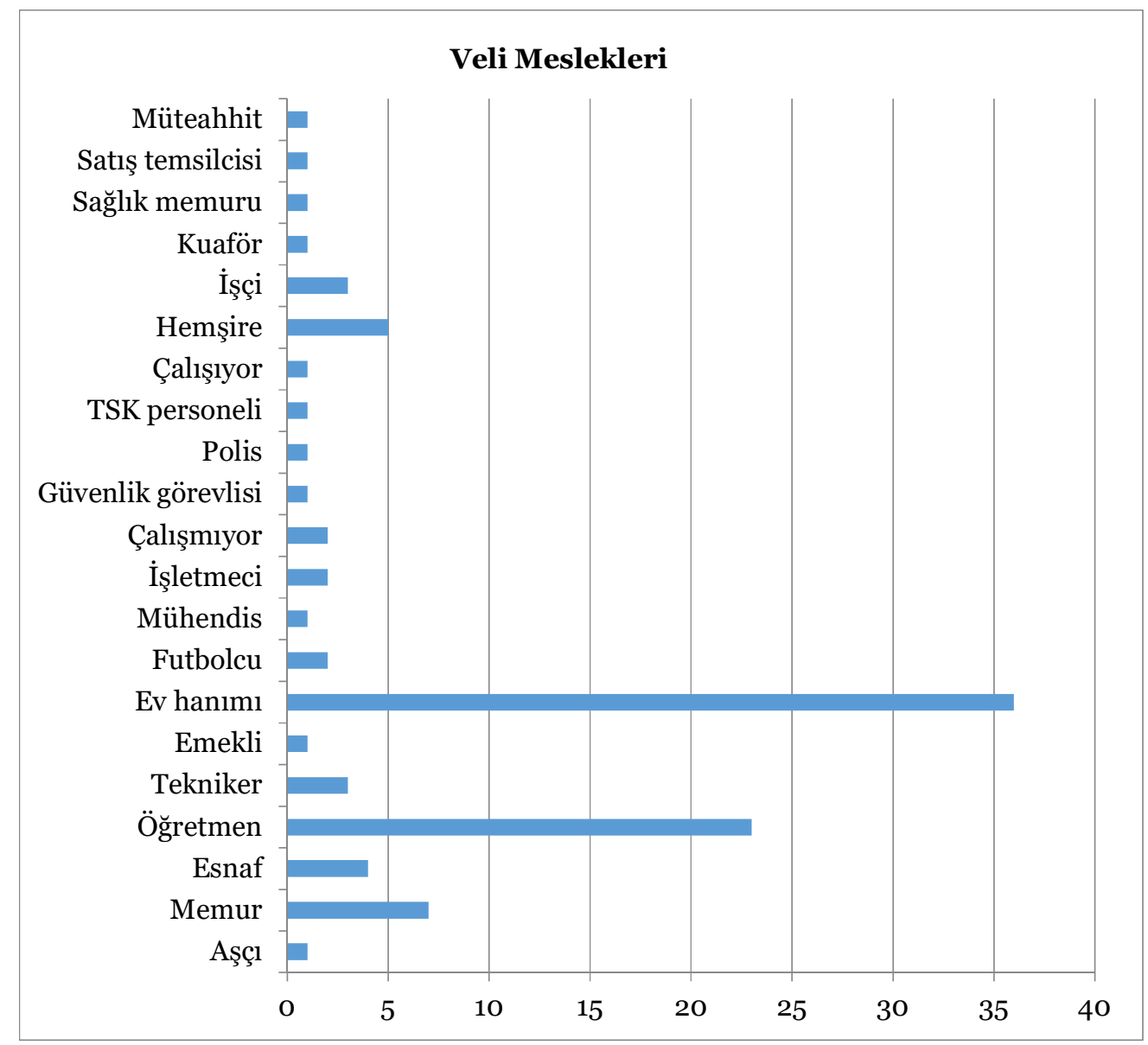

Grafik 9. Öğrenci velilerinin meslekî dağılımı

Grafik 9 incelendiğinde araştırmaya katılan velilerin en fazla $(\% 24,5)$ ev hanımı grubundan olduğu görülmektedir. $\mathrm{Bu}$ durumun, katılımcıların \% 67,6’sının kadın olmasıyla ilişkili olabileceği değerlendirilmektedir. Bunları takip eden meslekler ise öğretmen, memur ve hemşire olmaktadır.

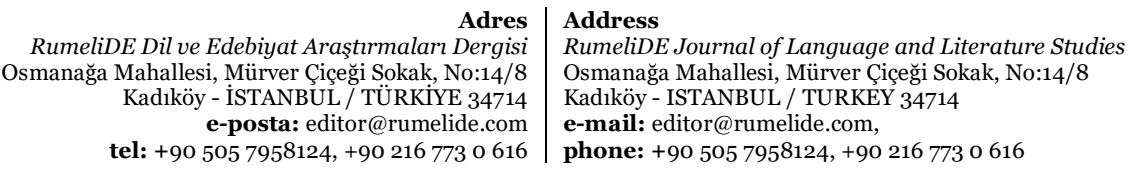




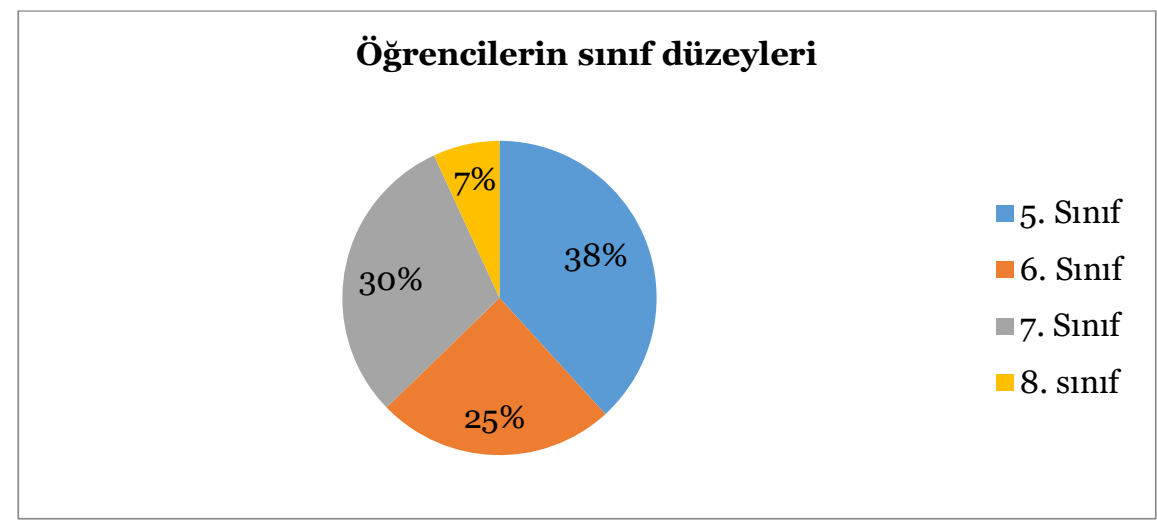

Grafik 10. Velisi bulunulan öğrencilerin sinıf düzeyleri

Metafor çalışmalarında elde edilen metafor cümleleri/önermeleri incelendikten sonra tasnif edilmekte ve temalandırılmaktadır. Veli metaforları ışığında yapılan temalandırmada ağırlıklı olarak benzer görüşlerin öne çıktı̆̆ı dikkat çekmektedir.

\begin{tabular}{ll}
\hline & Geçicilik \\
Temalar & Verimsizlik \\
& Ruhsuzluk \\
& İkame \\
\hline
\end{tabular}

Tablo 6. Veli metaforlarmda temalar

Temalar incelendiğinde veli görüşlerine göre uzaktan eğitimin metaforik algısında geçici olma, verimden uzak olma, yüz yüze eğitimin yerine ikame edilme ve ruhsuz, duygusuz, sosyalleşmeden uzak bir süreç olma durumları daha çok ifade edilmiştir. Öğrenci velilerinden elde edilen metaforlardan bazıları şöyledir:

V15 : Uzaktan eğitim vitamin ilacı gibidir. Çünkü takviye niteliğindedir. (İkame)

V61 : Uzaktan eğitim sanal aşk gibidir. Çünkü sevdiğiniz öğretmenlerle sanal iletişim kuruyorsunuz. (Ruhsuzluk)

V78 : Uzaktan eğitim baharatları ve tuzu katılmamış yemek gibidir. Çünkü tadı da tuzu da yoktur. (Verimsizlik)

V91 : Uzaktan eğitim boş bir defter gibidir. Çünkü bilgileri yazmazsan kahıı olmaz unutulur. (Geçicilik)

Ayrıca öğrenci velilerinin metaforları incelendiğinde yoğunlaşılan temalar haricinde dikkat çekici bazı metaforlar da yer almaktadır. Bunlardan bazılar şöyledir:

V4 : Uzaktan eğitim yağmur gibidir. Çünkü kimisi ıslanmaktan hoşlanır kimisi hemen şemsiyesini açar. Yani tamamen isteğe bağh bir sistem, zorlama yok. (Görecelik)

V5o : Uzaktan eğitim akademik destek gibidir çünkü bilinmeyen konularda intenet üzerinden konuşulur ve yardımlaşılır. (Faydalılık)

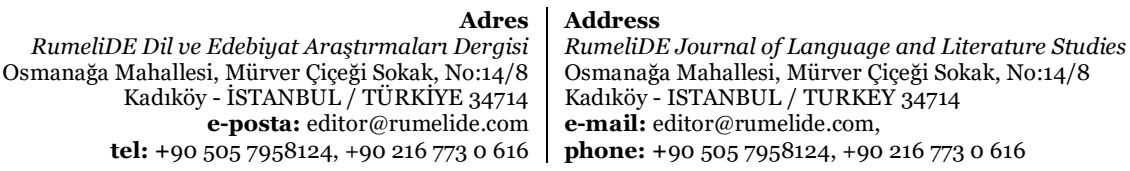


V62 : Uzaktan eğitim bir deniz gibidir. Çünkü bilgiler isteğe bağh ve cesur öğrenciler için olabildiğince bol ve sinırszzdır. Boğulmaktan korkmadan istediği kadar faydalanılabilir. (Zenginlik)

\section{Sonuç, tartışma ve öneriler}

Covid-19 salgını ile başlayan uzaktan eğitim sürecine yönelik öğrenci, öğretmen ve velilerin metaforik algılarının belirlenmesini amaçlayan bu araştırmada, katılımcıların ifade ettikleri metaforlarda çeşitli alternatiflerle uzaktan yapılan eğitimin verimli olmadığı, öğrencilerin eğitim ortamı içerisindeki sosyalleşmeden uzak kaldığı, yüz yüze eğitimin yerine ikame edilen ancak tam mânâsıly bu boşluğu dolduramayan bir uygulama süreci olduğu ifade edilmiştir.

Uzaktan eğitim sürecini ele alan çalışmalara bakıldığında uzaktan eğitim süreci; öğrenci, öğretmen ve velilerin metaforik algılarında sosyalleşmeden uzak ve ruhsuz bir süreç olarak ifade edilmiştir. Benzer sonuçlar Türkçe öğretmenleri üzerindeki araştırmada da ortaya konulmuştur (Karacaoğlu vd., 2021). Ayrıca Türkçe öğretmeni adayı olan lisans öğrencilerine yönelik çalışmada da öğrenciler bu süreçte kendilerini yeterince ifade edemediklerini, sosyalleşmeden uzak bir eğitim-öğretim dönemi geçirdiklerini belirtmişlerdir (Karakuş vd., 2020). Covid-19'a yönelik yapılan metafor çalışmasında Görgülü Arı ve Arslan (2020) ortaokul öğrencilerinin Covid-19'u sosyal ortamlardan uzaklaştırıcı bir durum olarak gördükleri sonucuna ulaşmışlardır. Keza çalışmamızda da metaforlar ile uzaktan eğitim sürecinin bireyleri sosyalleşmeden, sosyal ortamlardan, kişiler arası iletişimden uzaklaştırdığ tespit edilmiştir. Ekren ve Ökten (2019) öğreticilerin metaforlar aracılığıyla ortaya koyulan algılarının düşünce sistemlerinin bir parçası durumunda olduğunu, kişilerin eylemlerini düşüncelerinin bir uzantısı şeklinde gerçekleştirdikleri düşünüldüğünde de bu algılar doğrultusunda canlı derslerini, uzaktan eğitim sürecini sürdürdüklerini ifade etmek mümkündür.

Eğitim paydaşlarının metaforik algılarının tespitine yönelik yakın zamanda yapılmış metafor çalışmaları da bulunmaktadır. Çokyaman ve Ünal'ın (2020) öğrenci ve öğretmen metaforlarına ilişkin çalışması incelendiğinde öğrenci grubunda daha çok olumsuz metaforlar bulunurken öğretmen grubunda olumlu metaforların daha fazla olduğu belirtilmektedir. Aynı çalışmada öğrencilerin uzaktan eğitimin motivasyon, beklenti, duygu gibi duyuşsal öğeler içeren yönüne daha az önem verdikleri öğretmenlerin ise uzaktan eğitimin duyuşsal yönüne daha çok değer atfettikleri ortaya konulmuştur. Cantürk ve Cantürk’ün (2020) İngilizce öğretmenlerine yönelik metafor çalışmasında da etkileşim ile ilgili olumsuz durumlar ve uzaktan eğitim sürecinin verimsizliği tespit edilmiştir. Ayrıca aynı çalışmada sınıf yönetiminin daha kolay olmasına rağmen derse katılım oranlarının, etkileşimin ve derslerin veriminin ise çok düşük bir seviyede kaldığı ifade edilmiştir (Cantürk ve Cantürk, 2021). Akpolat'ın (2020) çalışmasında da hakeza öğrenciler uzaktan eğitimi etkileşimsiz, sanal ve yalnızlaştırıcı olarak algılamaktadırlar.

Ortaokul öğrencileri üzerinde metafor analizi yapan Akpolat'ın (2020) çalışmasında öğrenciler uzaktan eğitimi kurtarıcı olarak algılamaktadırlar. Öğrenciler salgın sürecinde eğitimlerinin kesintiye uğramamasını sağlayan uzaktan eğitimi hasta çorbası, ilaç ya da ilk yardım çantası olarak görmüş, tam olarak tedavi etmese de anlık durumu kurtardığını dile getirmişlerdir (Akpolat, 2020). Bu durum çalışmamızda benzer şekilde ortaya çıkmakta öğretmen, öğrenci ve velilerden alınan metaforik ifadelerde uzaktan eğitimi yüz yüze eğitim yerine ikame edilen, geçici de olsa uygulandı̆̆ sağlayan bir eğitim-öğretim süreci olarak ifade etmişlerdir. Kaplan ve Gülden (2021) de uzaktan eğitimi, barındırdığı olumlu ve olumsuz özellikleri ile tek başına yeterli olmayan ancak yüz yüze eğitimin yapılamadığı durumlarda destekleyen, tamamlayan bir süreç olarak ifade etmiştir.

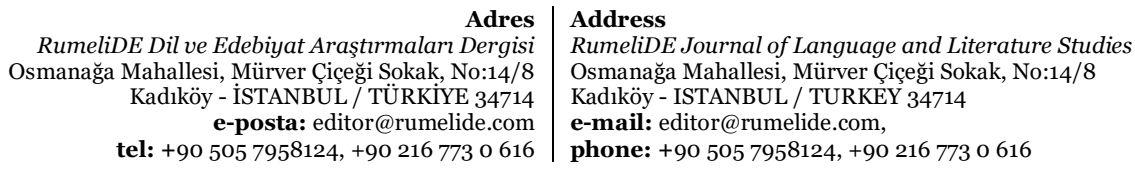


Araştırmaya katılan eğitim paydaşlarının uzaktan eğitim sürecini nasıl ve ne şekilde algıladığına dayalı metaforlar uzaktan eğitim sürecinde derslerin veriminin düşük olduğunu, geçici bir süreç olarak ancak yüz yüze eğitimi belli oranda ikame edebildiğini, öğretime dayalı uygulamaların bir nebze de olsa yapılabilmesine rağmen eğitim boyutunun ve sosyalleşmenin çok eksik kaldığını ortaya koymuştur. Eğitim-öğretimin sadece mekâna bağlı olmayan yaşayan bir süreç olduğu düşünüldüğünde uzaktan eğitim bu süreci olumsuz etkilemektedir (Karacaoğlu vd., 2021).

Araştırmada ulaşılan sonuçlar ışı̆̆ında uzaktan eğitim sürecine ilişkin birtakım öneriler sunulabilir:

- Uzaktan eğitime erişimle ilgili yaşanılan sıkıntılar metaforlarda da dile getirilmiştir. Geçici bir süreç olmasına rağmen yüz yüze eğitim yerine ikame edilen bu uygulamanın ileride yaşanabilecek benzer durumlara uygun hâle getirilmesi, buna uygun altyapı ve donanım çalışmalarının yürütülmesi gerekmektedir.

- Canlı ders ve diğer uzaktan eğitim uygulamalarında yer alan içerikler öğrencilerin ilgi, ihtiyaç ve istekleri doğrultusunda zenginleştirilmelidir.

- Yüz yüze eğitimden uzak kalan öğrencilerin motivasyonlarının azaldığı ve sosyal iletişimlerinin/etkileşimlerinin büyük ölçüde azaldığı tespit edilmiştir. Bu durumun duyuşsal ve duygusal gelişim açısından istenmeyecek durumlara neden olmaması için rehberlik saatleri, öğrenci görüşmeleri yapılmalıdır. Öğrencilerin sosyalleşmesini destekleyici çevrimiçi seminer, eğitici oyun, münazara ve bilgilendirmeler hazırlanmalıdır.

\section{Kaynakça}

Akgül, G., Oran M. (2021). Sosyal bilgiler öğretmenlerinin, ortaokul öğrencilerinin ve öğrenci velilerinin pandemi sürecindeki uzaktan eğitime ilişkin görüşleri. Eğitimde Yeni Yaklaşımlar Dergisi, 3(2), 15-37.

Akpolat, T. (2020) Ortaokul Öğrencilerinin Uzaktan Eğitime İlişkin Metaforik Algılarının İncelenmesi. Ankara University Journal of Faculty of Educational Sciences (JFES), (Gelecek Sayl), 497-522.

Arslan, K. Görgülü Arı, A., Hayır Kanat M. (2021) Covid-19 pandemi sürecinde verilen uzaktan eğitim hakkında veli görüşleri, ulakbilge, 57/2021 Şubat: s. 192-206. doi: 10.7816/ulakbilge-09-57-03

Balaman, F., \& Hanbay Tiryaki, S. (2021). Corona Virüs (Covid-19) Nedeniyle Mecburi Yürütülen Uzaktan Eğitim Hakkında Öğretmen Görüşleri. Itobiad: Journal of the Human \& Social Science Researches, $10(1)$.

Baltacı, A. (2019). Nitel araştırma süreci: Nitel bir araştırma nasıl yapılır? Ahi Evran Üniversitesi Sosyal Bilimler Enstitüsü Dergisi, 5(2), 368-388.

Başaran, M., Doğan, E., Karaoğlu, E., Şahin, E. (2020). Koronavirüs (Covid-19) pandemi sürecinin getirisi olan uzaktan eğitimin etkililiği üzerine bir çalışma. Academia Eğitim Araştırmaları Dergisi, 5(2), 368-397.

Bayburtlu, Y. S. (2020). Covid-19 pandemi dönemi uzaktan eğitim sürecinde öğretmen görüşlerine göre Türkçe eğitimi. Turkish Studies, 15(4), 131-151.

Bloor, M., Wood, F. (2006). Phenomenological methods. Keywords in qualitative methods, 129-131.

Bozkurt, A. (2020). Koronavirüs (Covid-19) pandemisi sırasında ilköğretim öğrencilerinin uzaktan eğitime yönelik imge ve algıları: bir metafor analizi. Uşak Üniversitesi Eğitim Araştırmaları Dergisi, 6(2), 1- 23.

Buluk, B., Eşitti, B. (2020). Koronavirüs (Covid-19) sürecinde uzaktan eğitimin turizm lisans öğrencileri tarafindan değerlendirilmesi. Journal of Awareness, 5(3), 285-298.

$$
\text { Adres } \mid \text { Address }
$$

RumeliDE Dil ve Edebiyat Araşturmalar Dergisi $\quad$ RumeliDE Journal of Language and Literature Studies

Osmanağa Mahallesi, Mürver Çiçeği Sokak, No:14/8 Osmanağa Mahallesi, Mürver Çiçeği Sokak, No:14/8

Kadıköy - ISTANBUL / TÜRKIYE 34714 Kadıköy - ISTANBUL / TURKEY 34714

e-posta: editor@rumelide.com e-mail: editor@rumelide.com,

tel: +90 505 7958124, +90 2167730616 phone: +90 505 7958124, +90 2167730616 
Cantürk, G., Cantürk, A. (2021). İngilizce öğretmenlerinin covıd-19 küresel salgını sürecinde gerçekleştirdikleri uzaktan eğitim deneyimleriyle ilgili görüşlerinin metaforlar yoluyla belirlenmesi. International journal of current approaches in language, education and social sciences, 3(1), 688-724.

Creswell, J. W. (2017). Eğitim araştırmaları. İstanbul: EDAM Eğitim Danışmanlığı ve Araştırmaları Merkezi.

Çilesiz, S. (2011). A phenomenological approach to experiences with technology: current state, promise, and future directions for research. Educational Technology Research and Development, 59(4), 487-510.

Çokyaman, M., Ünal, M. (2020) Öğrenci ve öğretmenlerin covid-19 salgını dönemindeki uzaktan eğitim algısı: bir metafor analizi. OPUS uluslararası toplum araştırmaları dergisi, 18 (yönetim ve organizasyon özel sayısı), 1684-1715.

Demirbilek, N. (2021). Üniversite öğrencilerinin uzaktan öğretime ilişkin metaforik algıları/metaphoric perceptions of university students on distance education. E-uluslararası eğitim araştırmaları dergisi, 12(1), 1-15.

Ekren, C., Ökten, C. E. (2019). Yabancılara Türkçe öğretenlerin dil bilgisi öğretimine ilişkin algıları: bir metafor incelenmesi. Uluslararası Türkçe edebiyat kültür eğitim (TEKE) dergisi, 8(3), 16871708.

Erlingsson, C., Brysiewicz, P. (2017). A hands-on guide to doing content analysis, African Journal of Emergency Medicine, 7(3), 93-99.

Ertuğ, C. (2020). Coronavirüs (Covid-19) pandemisi ve pedagojik yansımaları: Türkiye'de açı ve uzaktan eğitim uygulamaları. Açıöŏgretim Uygulamaları ve Araştırmaları Dergisi, 6(2), 11-53.

Genç, M. F., Gümrükçüoğlu, S. (2020). Koronavirüs (covıd-19) sürecinde ilâhiyat fakültesi öğrencilerinin uzaktan eğitime bakışları. electronic Turkish studies, 15(4).

Kaplan, K., Gülden, B. (2021). Öğretmen görüşlerine göre salgın (covid-19) dönemi uzaktan eğitim ortamında Türkçe eğitimi. Rumelide dil ve edebiyat araştırmaları dergisi, (24), 233-258.

Karacaoğlu, M. Ö., Karakuş, N., Esendemir, N., Ucuzsatar, N. (2021). Uzaktan eğitim üzerine bir araştırma: "Türkçe öğretmenleriyle mülakatlar". IJLA International Journal of Language Academy, 9 (1), 124-144

Karadağ, E., Yücel, C. (2020). Yeni tip koronavirüs pandemisi döneminde üniversitelerde uzaktan eğitim: lisans öğrencileri kapsamında bir değerlendirme çalışması. Yükseköğretim Dergisi, 1O(2), 181-192.

Karakuş, N., Ucuzsatar, N., Karacaoğlu, M. Ö., Esendemir, N., Bayraktar, D. (2020). Türkçe öğretmeni adaylarının uzaktan eğitime yönelik görüşleri. RumeliDE Dil ve Edebiyat Araştırmaları Dergisi, (19), 220-241.

Karakus,, N., Esendemir, N., Ucuzsatar, N., Karacaoğlu, M. Ö. (2021). Türkçe dersleri özelinde uzaktan eğitim hakkında veli görüşleri. Ana Dili Eğitimi Dergisi, 9(3), 993-1011.

Kırmızıgül, H. G. (2020). Covid-19 salgını ve beraberinde getirdiği eğitim süreci. Avrasya sosyal ve ekonomi araştırmaları dergisi, 7(5), 283-289.

Korkmaz, E. (2021). İlköğretim matematik öğretmenlerinin metaforik algıları: pandemi sürecinde matematiğe yönelik farklı kavramlar. Mustafa kemal üniversitesi eğitim fakültesi dergisi, 5(7), 114 .

Kuzu, İ. Y., Bahçeci, F., Yalçın, C. K. (2021). Öğretmenlerin koronavirüs pandemisi döneminde verdikleri uzaktan eğitime ilişkin metaforik alglları. Frrat üniversitesi sosyal bilimler dergisi, 31(2), 701-715.

Kürtüncü, M., Kurt A. (2020). COVID-19 pandemisi döneminde hemşirelik öğrencilerinin uzaktan eğitim konusunda yaşadıkları sorunlar. Avrasya sosyal ve ekonomi araştırmaları dergisi, 7(5), 66-77.

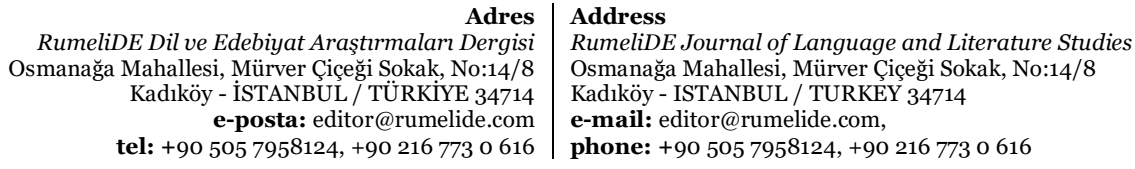


MEB. (12 Mart 2020). Bakan Selçuk, koronavirüs'e karşı eğitim alanında alınan tedbirleri açıkladı. [http://www.meb.gov.tr/bakan-selcuk-koronaviruse-karsi-egitim-alaninda-alinan-tedbirleriacikladi/haber/20497/tr adresinden 06.05.2020 tarihinde erişilmiştir.]

MEB. (19 Kasım 2020). Uzaktan eğitime geçilmesiyle ilgili genelge. https://www.trthaber.com/haber/guncel/mebden-81-ile-uzaktan-egitim-genelgesi-4-ocakakadar-sinav-yok- [19 Kasım 2020 tarihinde erişilmiştir]

Merriam, S. B. (2018). Nitel araştırma: desen ve uygulama için bir rehber. Ankara: nobel akademik yayıncilık.

Özdoğan, A. Ç., \& Berkant, H. G. (2020). Covid-19 pandemi dönemindeki uzaktan eğitime ilişkin paydaş görüşlerinin incelenmesi. Milli Ĕ̆itim Dergisi, 49(1), 13-43.

Öztürk, D., Koca, A. H. D.(2021) Ortaokul Öğrencilerinin Laboratuvar Ve Uzaktan Eğitim Kavramlarına Yönelik Metaforik Algıları. Anadolu Ögretmen Dergisi, 5(1), 179-199.

Patton, M. Q. (2014). Nitel araştırma yöntemleri. Ankara: Pegem Akademi.

Şeren, N., Tut, E., Kesten, A. (2020). Korona virüs sürecinde uzaktan eğitim: Temel eğitim bölümü öğretim elemanlarının görüşleri. Turkish Studies, 15(6), 4507-4524.

YÖK. (13 Mart 2020). Koronavirüs (covid-19) bilgilendirme notu: 1. [https://www.yok.gov.tr/sayfalar/haberler/2020/coronavirus_bilgilendirme_1.aspx adresinden 15.11.2020 tarihinde erişilmiştir.]

Willig, C. (2008). Introducing qualitative research in psychology (2. Baskı). berkshire: mcgraw-hill professional publishing.

RumeliDE Dil ve Edebiyat Araşturmaları Dergisi Osmanağa Mahallesi, Mürver Çiçeği Sokak, No:14/8 Kadıköy - İSTANBUL / TÜRKIYE 34714 e-posta: editor@rumelide.com tel: +90 $5057958124,+902167730616$
Address

RumeliDE Journal of Language and Literature Studies Osmanağa Mahallesi, Mürver Çiçeği Sokak, No:14/8

Kadıköy - ISTANBUL / TURKEY 34714

e-mail: editor@rumelide.com,

phone: +90 $5057958124,+902167730616$ 